\title{
Parent and Infant Temperament and Parenting Styles of Rural Agrarian Parents of Telangana
}

\author{
V. Kavitha Kiran and K. Yashoda*
}

All India Coordinated Research Project on Home Science, Human Development Component, PGRC, PJTSAU, Rajendranagar, Hyderabad-30, India

*Corresponding author

\section{Keywords}

Parent and Infant temperament, Rural Agrarian parents

Article Info

Accepted:

17 September 2019

Available Online:

10 October 2019

\section{A B S T R A C T}

Present study was taken up to find out the Parent and Infant temperament and Parenting styles of rural agrarian parents 300 couples (150 Mothers and 150 fathers) of Telangana from the adopted villages of Maheshwaram Mandal, Ranga Reddy district, Hyderabad. Results concluded Majority of Rural mothers were authoritative and fathers were Permissive. Parents can adapt parenting style to suit child's individual temperament so that the child develops the positive parts of her temperament.

\section{Introduction}

Temperament defined as a set of inherited personality traits that appear early in life. The two defining characteristics include the traits that are genetic in origin, like any psychological dispositions inherited (e.g. intelligence) and second, the traits appear in infancy, specifically during the first year of life. This distinguishes temperament from groups of personality traits, both inherited and acquired (Buss and Plomin, 1987). Temperament can be said as the way children respond to the world. It can be explained in terms of three qualities, reactivity, self regulation and sociability. Each child is born with her own temperament. Characteristics of temperament are activity level, distractibility, adaptability, sensitivity and quality of mood. There are three major types of temperament, easy, slow to warm up and difficult. Parents have important roles in child rearing, but the influence of their personality on rearing practices and their impact on child behavior. Parenting and temperament combine to predict child outcomes, for instance parental warmth (support and affection) and firm control.

Thomas and Chess (1977), proposed nine dimensions of temperament, which are activity level, adaptability, attention span and persistence, distractibility, approach/ withdrawal, rhythm city, quality of mood, threshold of responsiveness and intensity of 
reaction.

Set of parenting approaches, objectives, and patterns of parenting behaviours, thought to establish an optimal emotional environment for the occurrence of parenting behaviour defined as parenting style (Darling and Steinberg, 1993) In studies of parenting styles, demandingness is the expectation that parents have for their child to incorporate into the family structure by demanding maturity and providing guidance, supervision, firm discipline and confrontation of misbehaviour, whereas responsiveness is characterised as the degree to which parents deliberately foster individuality and self-regulation in their child (Baumrind, 1996; Maccoby and Martin, 1983). Parenting behaviour as a direct combination of demandingness and responsiveness rather than multiple dimensions of parenting behaviours, Baumrind (1967, 1971). To foster a positive emotional environment that might encourage individuality and self-expression appropriate balance between demandingness and responsiveness is required (Baumrind, 1991). From the parenting typologies of demandingness and responsiveness, four widely known parenting styles are proposed (Baumrind, 1966, 1967, 1971), namely authoritative, authoritarian, permissive, and uninvolved. Parenting that is warm, responsive, involved, yet unintrusive and in which parents set reasonable limits and expect appropriately mature behavior is referred as Authoritative. Parenting that is harsh, unresponsive, rigid where parents tend to use power assertive methods of control is Authoritarian. Permissive style is refers to parenting that is lax, and in which parents exercise 14 inconsistent discipline and encourage children to express their impulses freely. Maccoby and Martin (1983) extended Baumrind's typology and added the fourth parenting style of 'neglecting' or 'uninvolved' Aim of the study
To study the temperament dimensions influencing the parenting style

\section{Materials and Methods}

\section{Locale of the study area}

Five adopted villages of Maheshwaram Mandal

\section{Research design}

Quasi experimental design will be adopted through pre and post single group study

\section{Sample}

Sample will be comprised of 300 couples (150 fathers and 150 mothers).

\section{Tools}

Parenting style questionnaire based on: Robinson et al., (1995). Authoritative, authoritarian, and permissive parenting practices: Development of a new measure. Psychological Reports, 77, 819-830.

Adult Temperament Questionnaire was prepared after thorough review of literature. It was pre tested and necessary changes were made. Both the questionnaires were translated to Telugu local language.

\section{Results and Discussion}

With regard to Parenting styles of rural mothers, out of 300 mothers, $55 \%$ were following Authoritative style, $33 \%$ were following Permissive style and only $12 \%$ were following Authoritarian style of parenting with their young children.

With regard to Parenting styles of rural fathers, out of 300 fathers, $45 \%$ were following Permissive style, $32 \%$ were 
following Authoritative style and only 23\% were following Authoritarian style of parenting with their young children.

With regard to Parental temperament of rural mothers, out of 300 mothers, $52 \%$ had average kind of (slow to warm up) of temperament, 28\% had Highly positive temperament and only $20 \%$ had less positive temperament in general.

With regard to Parental temperament of rural fathers, out of 300 fathers, $50 \%$ had average kind of (slow to warm up) of temperament, $37 \%$ had less positive temperament and only $13 \%$ had Highly positive temperament in general.

With regard to Infant temperament, out of 150 children, 49\% had average kind of (slow to warm up) of temperament, 33\% had less positive temperament and only $18 \%$ had Highly positive temperament in general.

Parents can adapt parenting style to suit child's individual temperament so that the child develops the positive parts of her temperament. If child is very reactive, who are often physically active and might need lots of time outdoors. The child should be encouraged to try new sporting activities, A less reactive child is usually easy to get al.,ong with, but might be less assertive. Teach this child how to stand up for himself. For example, in situations where the child could be more assertive, get him to practice handling those situations differently. It's also important to make sure less reactive children aren't left out of family discussions. Children who are less reactive might also be less physically active. Your less active child will be happiest with lots of opportunities to use her fine motor skills, like doing craft or drawing. Children who find it easier to self-regulate are good at managing their reactions to emotions like frustration or excitement. They can calm down faster after something exciting or upsetting, and they're less impulsive. If the child has difficulty regulating attention, need lots of encouragement to keep going at difficult tasks. These children might switch quickly from one activity to another. They can also be very creative. To help your child focus, try rewarding child or making things fun by using games and creative activities (Table 1$5)$.

Table.1 Parenting styles scores of rural mothers with young children

\begin{tabular}{|c|c|c|c|}
\hline Total & $\begin{array}{l}\text { Parenting } \\
\text { style }\end{array}$ & $\begin{array}{c}\text { No and } \\
\%\end{array}$ & $\begin{array}{l}\text { Rank } \\
\text { order }\end{array}$ \\
\hline \multirow[t]{3}{*}{300} & Authoritative & $164(55 \%)$ & 1 \\
\hline & Authoritarian & $38(12 \%)$ & 3 \\
\hline & Permissive & $98(33 \%)$ & 2 \\
\hline
\end{tabular}

Table.2 Parenting styles scores of rural fathers with young children

\begin{tabular}{|c|c|c|c|}
\hline & & & $\mathrm{N}=300$ fathers) \\
\hline Total & Parenting style & No and \% & Rank order \\
\hline \multirow[t]{3}{*}{300} & Authoritative & $96(32 \%)$ & 2 \\
\hline & Authoritarian & $69(23 \%)$ & 3 \\
\hline & Permissive & $135(45 \%)$ & 1 \\
\hline
\end{tabular}


Table.3 Parental temperament scores of rural mothers with young children

\begin{tabular}{|c|c|c|c|}
\hline Total & $\begin{array}{c}\text { Less positive } \\
\text { (Difficult) }<45 \\
\text { N and \% }\end{array}$ & $\begin{array}{c}\text { Average (Slow to } \\
\text { warm-up) 46-90N } \\
\text { and \% }\end{array}$ & $\begin{array}{c}\text { Highly positive (Easy) } \\
\text { 91-135N and \% }\end{array}$ \\
\hline $\mathbf{3 0 0}$ & $85(28 \%)$ & $155(52 \%)$ & $60(20 \%)$ \\
\hline
\end{tabular}

Table.4 Parental temperament scores of rural fathers with young children

\begin{tabular}{|c|c|c|c|}
\hline Total & $\begin{array}{c}\text { Less positive } \\
\text { (Difficult) < 45 } \\
\text { N and \% }\end{array}$ & $\begin{array}{c}\text { Average (Slow to } \\
\text { warm-up) 46-90 } \\
\text { N and \% }\end{array}$ & $\begin{array}{c}\text { Highly positive (Easy) } \\
\text { 91-135N and \% }\end{array}$ \\
\hline $\mathbf{3 0 0}$ & $111(37 \%)$ & $150(50 \%)$ & $39(13 \%)$ \\
\hline
\end{tabular}

Table.5 Infant temperament scores

\begin{tabular}{|c|c|c|c|}
\hline Total & $\begin{array}{c}\text { Less positive } \\
\text { (Difficult) < 38 } \\
\text { N and \% }\end{array}$ & $\begin{array}{c}\text { Average (Slow to } \\
\text { warm-up) 39-76 }\end{array}$ & $\begin{array}{c}\text { Highly positive } \\
\text { (Easy) 77-114 } \\
\text { N and \% }\end{array}$ \\
\hline $\mathbf{1 5 0}$ & $49(33 \%)$ & $74(49 \%)$ & $27(18 \%)$ \\
\hline
\end{tabular}

References

Baumrind, D. (1966). Effects of authoritative control on child behavior. Child Development, 37, 887-907.

Baumrind, D. (1967). Child care practices anteceding three patterns of preschool behavior. Genetic Psychology Monographs, 75, 43-88.

Baumrind, D. (197 la). Current patterns of parental authority. Developmental Psychology Monograph, 4 (1, Pt. 2).

Baumrind, D. (1991a). Parenting styles and adolescent development. In J. BrooksGunn, R. Lerner, and A. C. Petersen (Eds.), The encyclopedia of adolescence (pp. 746-758). New York: Garland

Buss, A.H., and Plomin, R. Temperament: Early developing personality traits. Hillsdale, NJ: Erlbaum, 1987.

Darling and Steinberg, 1993. The relation of parenting style to adolescent school performance. Child Development, 58, 1244-1257.

Maccoby, E. E., and Martin, J. A. (1983). Socialization in the context of the family: Parent-child interaction. In $\mathrm{P} . \mathrm{H}$. Mussen (Series Ed.) and E. M. Hetherington (Vol. Ed.), Handbook of child psychology: Vol. 4. Socialization, personality, and social development (4th ed., pp. 1 -101) New York: Wiley.

Robinson, C., Mandleco, B., Olsen, S. F., and Hart, C. H. (1995). Authoritative, authoritarian, and permissive parenting practices: Development of a new measure. Psychological Reports, 77, 819-830.

Thomas, A., and Chess, S. Temperament and development. New York: Brunner/Mazel, 1977.

\section{How to cite this article:}

Kavitha Kiran, V. and Yashoda, K. 2019. Parent and Infant Temperament and Parenting Styles of Rural Agrarian Parents of Telangana. Int.J.Curr.Microbiol.App.Sci. 8(10): 2232-2235.

doi: https://doi.org/10.20546/ijcmas.2019.810.259 